\title{
Tooth or dare?
}

In this ever-evolving world of scientific advancement, a meteoric blast from the past might be just what the planet needs, according to a team at the University of Kinderos Buenos in South America.

The team has discovered pulpal stem cells in fossilised tooth remains. They believe it is only a matter of time before dinosaur safaris become a reality.

Dr Rawry Claws, who headed the team, gave a press conference earlier this month at which he hailed the discovery as the 'fearless existence of troubled species that can be raised from the dead long after their expiration date, thus questioning Darwin's theory of survival of the fittest.

Rumours amongst palaeontology circles are now rife about the existence of guarded warehouses with eggs ready to hatch at any moment.

There is also speculation that 'Neu-neu, we told you so' invitations will be offered to the world's most prominent prehistoric experts to peruse the game park with tickets being made available to the general public soon after.

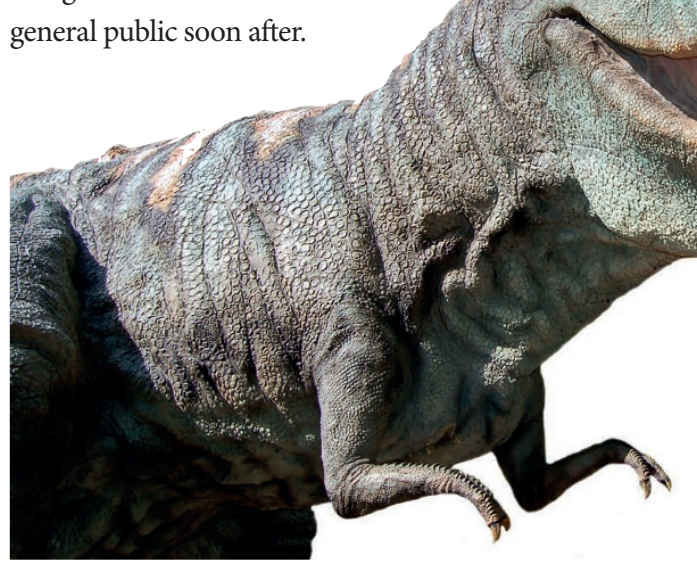

It is hoped whisperers and tamers can assist in calming these rediscovered beasts to prevent the riotous

Satellite images on Leakopedia have reported that spatial enclosures have been created at Area 51 to house the larger than life creatures. Furthermore, leaked documents have shown soon-to-be-advertised positions for veterinarians and dentists, especially in search of those specialised in supersized macrodontology.

The job specification clearly requests dentists with climbing experience who are not afraid to scale giant structures. Those with knowledge of setting up drilling platforms is desired, but not essential, as full ํㅡㄹ training and support would be provided.

Fear of being eaten alive, however, is obviously a contraindication.

For candidates brave enough to apply, perks include reduced indemnity fees since displeased patients will probably exercise termination of the clinician(s) rather than seek pay-outs or regulatory hearings. Other incentives listed are a substantial salary in proportion to the mammoth tusks ahead, relocation package, and full pension if the candidate is lucky enough to make it to retirement age.

In an effort to ease reservations of those applying for any roles, a statement accompanies the job description. It assures potential applicants that the artistic directors have taken the time to watch every disaster movie at their disposal to avoid repeat script writing and formulate sensible Health and Safety and RIDDOR policies.

(n) 